\title{
The effect of the Changjiang River on water regimes of its tributary Lake East Dongting
}

\author{
DAI Xue ${ }^{1,2},{ }^{*}$ YANG Guishan ${ }^{1}$, WAN Rongrong ${ }^{1}$, LI Yanyan ${ }^{1}$ \\ 1. Key Laboratory of Watershed Geographic Sciences, Nanjing Institute of Geography and Limnology, CAS, \\ Nanjing 210008, China; \\ 2. University of Chinese Academy of Sciences, Beijing 100049, China
}

\begin{abstract}
The blocking or reversing effect of the downstream trunk river on its tributary lakes is an essential aspect of river-lake hydraulics. To measure how and the extent to which a trunk river can influence its tributary lakes, we made a case study in Changjiang River and one of its tributary lakes, Lake East Dongting (Lake ED) during a 35-year study period (1980-2014). Specifically, we investigated Lake ED's discharge ability into Changjiang River using stage-discharge relationship curves, and hence the changes of the lake discharge ability under different hydrologic conditions of the Changjiang River. The results show that (1) the Changjiang River does exert a huge impact on the water regimes of Lake ED. And this impact varies seasonally. A variation of $3000 \mathrm{~m}^{3} / \mathrm{s}$ in Changjiang River's runoff would change the lake water level by about $1.1 \mathrm{~m}$ in dry seasons, by $0.4 \mathrm{~m}$ in wet seasons, and by $0.6 \mathrm{~m}$ during severe summer floods. (2) Changes in the Changjiang River runoff triggered by the Three Gorges Dam since 2003 have led to dramatic water regime variations in Lake ED. Other factors, including reduction of lake inflow and the lake bed erosion, also exacerbated the water regime variations in Lake ED.
\end{abstract}

Keywords: trunk river; tributary lake; Changjiang River; Lake East Dongting; stage-discharge relationship curve

\section{Introduction}

Lakes generally exhibit complex interactions with surrounding bodies of water, such as rivers, reservoirs, oceans, etc. (Cooke, 2005; Li et al., 2016). In general, the inflow of lakes depends greatly on bodies of water located upstreams, while the outflow of lakes, i.e., the water holding capacity of lakes, depends mainly on their interaction with those downstreams (Dai et al., 2015). While the role of upstream bodies of water in the water regime of lakes has been thoroughly studied in many regions, the impact of those downstreams has not received due to attention paid. In recent decades, the increasing construction of dams and res-

Received: 2017-08-14 Accepted: 2018-01-10

Foundation: Key Research Program of the Chinese Academy of Sciences, No.KFZD-SW-318; National Basic Research Program of China, No.2012CB417006; National Natural Science Foundation of China, No.41601041

Author: Dai Xue, PhD, specialized in ecohydrology and hydrobiology. E-mail: daixue1224@163.com

"Corresponding author: Yang Guishan, Professor, E-mail: gsyang@niglas.ac.cn 
ervoirs on rivers has changed the natural hydrologic regime of many rivers dramatically (Dynesius and Nilsson, 1994; Darwish et al., 2017). This situation has also altered the hydraulic connections between the trunk river and its tributary lakes (Guo et al., 2012; Gao et al., 2015). For example, reduction of runoff in Changjiang River due to the operation of the Three Gorges Dam has caused more outflow from its tributary lakes and has significantly lowered the water levels in those lakes, such as the Lake Dongting and the Lake Poyang, in southern China (Guo et al., 2012; Liu et al., 2013; Zhang et al., 2013b). Similar phenomena have also been observed in many other regions, such as Lake Athabasca in Canada (Peters and Buttle, 2010) and Lake Wakatipu in New Zealand (Waugh et al., 2006). Therefore, it is essential for hydrological scientists to consider the trunk river and the tributary lakes as an integrated system to better understand this complex interaction on a catchment level.

Great efforts have been made to the issue on how to measure the impact of a trunk river on its tributary lakes, especially regarding the above-mentioned water system, the midstream of the Changjiang River in southern China. Because hydrologic regime of Changiiang River is experiencing continuing pressures from different human activities (e.g. damming, dredging), the impacts of which on its numerous tributary lakes are attracting considerable interest for its international environmental importance. For example, Chang et al. (2010) measured the effect of the Changjiang River on the lake by comparing the runoff and sediment levels of Dongting Lake before and after 2003, the year when the Three Gorges Dam began operations on the Changjiang River. Similarly, Guo et al. (2012) studied two typical years before and after 2003 to detect the impact of the Changjiang River on its tributary Poyang Lake. Li et al. (2013) built a water exchange coefficient calculated from observational hydrologic data to quantify the effect of the Changjiang River on Dongting Lake. Hu et al. (2007) and Zhao et al. (2011) utilized another river-lake water exchange coefficients to quantify the effect of the Changiiang River on Poyang Lake. Zhang et al. (2014) utilized a hydrologic water balance perspective to quantify the effect of the Changjiang River on its tributary lakes. Almost all these insight studies have found a weakening of the Changjiang River's blocking effect on the outflow of its tributary lakes. However, it is still a baffling problem to precisely detect and quantitatively measure the impact of the trunk river on its tributary lakes.

In this paper, we present a new method to measure this effect, based on a case study in the Lake East Dongting (Lake ED), one of the tributary lakes of the Changjiang River at its midstream region (Yuan et al., 2015). Lake ED feeds into the Changjiang River through Chenglingji outlet. Hence, water regime of the Changjiang River determines the rate at which Lake ED can discharge into the river. In our method, we investigated Lake ED's discharge ability into the Changjiang River using stage-discharge relationship curves at the Chenglingji outlet. Then, we investigated the impact of the Changjiang River on Lake ED by comparing different rating curves yield under different hydrologic conditions of the Changjiang River. Specifically, we describe (1) recent water level changes in Lake ED, (2) the impact of the Changjiang River on Lake ED, (3) the variation amplitude of the lake water level trigged by the changing Changjiang River runoff since 2003, and (4) other factors that impact the water regime of Lake ED. Additionally, we argue that operation of the Three Gorges Dam would most likely be an indirect cause for the water regime changes within Lake ED, which works by changing hydrologic conditions of the trunk Changjiang River. As 
stated above, regulation of the dam that takes the water regimes of tributary lakes into account should be proposed.

\section{Data and methods}

\subsection{Study area}

In southern China, the Three Gorges Dam, the world's largest dam, was built on China's longest river, the Changjiang River (Yang et al., 2007; Wu et al., 2008). Several tributary lakes are located downstream from the dam, such as the Dongting Lake $\left(28^{\circ} 44^{\prime}-29^{\circ} 35^{\prime} \mathrm{N}\right.$, $\left.111^{\circ} 53^{\prime}-113^{\circ} 05^{\prime} \mathrm{E}\right)$ at approximately $300 \mathrm{~km}$ downstream and the Poyang Lake $\left(28^{\circ} 24^{\prime}-29^{\circ} 46^{\prime} \mathrm{N}, 115^{\circ} 49^{\prime}-116^{\circ} 46^{\prime} \mathrm{E}\right) 600 \mathrm{~km}$ downstream. Both lakes, which include large freshwater wetland areas that contain a great diversity and richness of species, are internationally recognized as home to many rare and endangered varieties (The Ramsar Convention, 2012).

The Dongting Lake catchment has a subtropical monsoon climate with an annual rainfall of $1364 \mathrm{~mm}, 61 \%$ of which occurs during March-July (Liao and Guo, 2014). Hence, the water regime of Dongting Lake follows the typical seasonal variations, with the lake water rising in spring, flooding in summer, retreating in autumn, and drying in winter. Based on surface area, Dongting Lake is the second largest freshwater lake in China, covering approximately $2579 \mathrm{~km}^{2}$. Thus, inevitable water-table discrepancies occur over the extensive surface. Traditionally, it is divided into three distinct sub-lakes: The Lake Western Dongting, the Lake Southern Dongting and the Lake Eastern Dongting (Lake ED) (Dong and Zou, 2014), as shown in Figure 1. Lake ED accounts for over one-third of the total area of Dongting Lake. The only outlet of the Dongting Lake, i.e. the Chenglingji outlet, is in this region. That is, Lake ED is the connecting region at which the Dongting Lake links to the Changjiang River. Therefore, the hydrodynamic effect of the trunk Changjiang River is intensified and more complex at Lake ED.

\subsection{Data collection}

Daily water level and discharge data (1980-2014) at two gauging stations, i.e., the Chenglingji station and the Jianli station, were used in this study. Jianli station, marked by a red dot in Figure 1, is located in the most strikingly meandering section of the middle Changjiang River, i.e., the Jianli reach. It is connected with Dongting Lake at tail reach. Chenglingji station is located exactly at this connection, which is also marked by a red dot in Figure 1. Thus, Jianli station, located at the main opening of the Jianli reach, can monitor the hydrologic conditions of the Changjiang River. While Chenglingji station, located on the outlet of the Dongting Lake, can monitor the water regimes of Lake ED. All those daily data are from the Hydrological Bureau of Jiangxi Province (http://www.jxsl.gov.cn/), which are continuous with no missing values.

\subsection{Approaches to estimating the main stream impact on its tributary lakes}

Stage-discharge relationship curves (also referred to as Rating curves) are widely used in the water hydraulics field to assess the capacity for conveying water (Dottori et al., 2009; Wolfs and Willems, 2014). Hence, the rating curves of Chenglingji outlet were used to investigate 


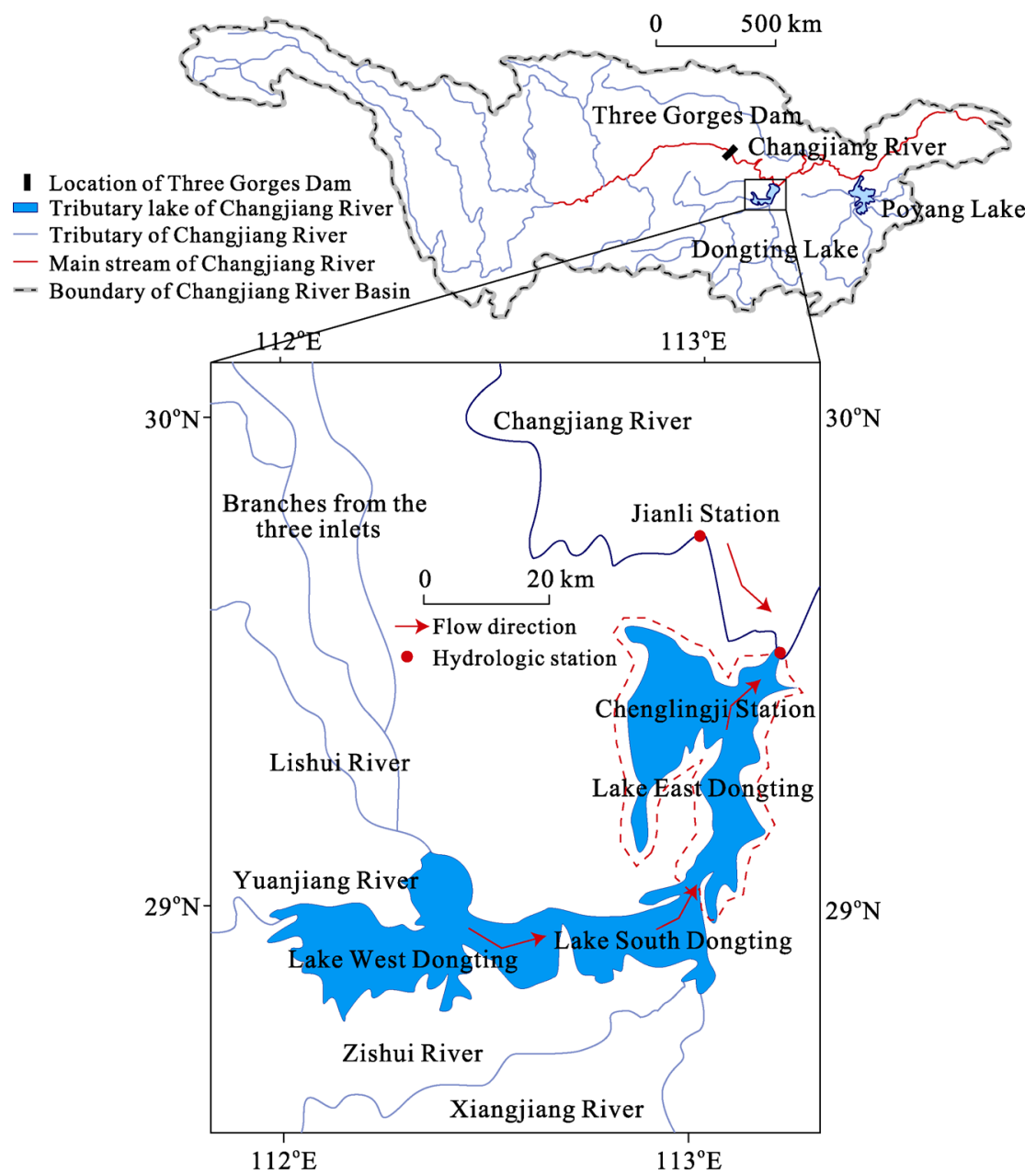

Figure 1 Location and geological map of Lake East Dongting

Lake ED's discharge ability in this study. To quantify the impact of the Changjiang River on the Lake ED's discharge ability, different rating curves of Lake ED yield under different hydrologic conditions of the Changjiang River were compared. To be specific, the rating curves of Lake ED were fitted separately in each group, which were divided by the evenly spaced Changjiang River runoff. The average distance between adjacent rating curves was calculated as the water level variation amplitude of Lake ED triggered by the variation of Changjiang River runoff, as shown in Figure 2.

In each group divided by the certain range of the Changjiang River runoff, a power-law function fit the rating curve of Lake ED as follows:

$$
H_{\text {Lake }}=a Q_{\text {Lake }}^{b}
$$

Power-law function is commonly untilized and proved to be effective in many hydrometric practice for rating curve (Leon et al., 2006; Dottori et al., 2009; Jalbert et al., 2011; Wolfs and Willems, 2014; Kashani et al., 2015). In this equation, $Q_{\text {Lake }}$ is the discharge of Lake ED $\left(\mathrm{m}^{3} / \mathrm{s}\right), H_{\text {Lake }}$ is the water level of Lake ED $(\mathrm{m}), a$ and $b$ are empirical parameters.

This method measures the impact of the Changjiang River on water regimes of Lake ED via the detection of lake water level variation amplitude at equal lake discharge under 


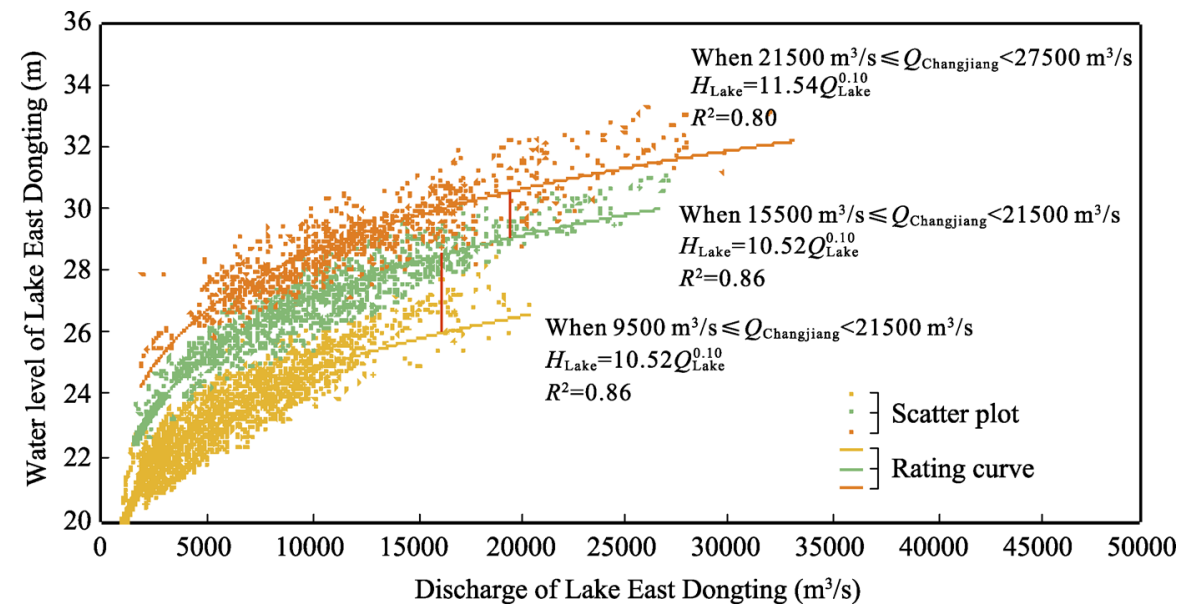

Figure 2 An example of how to measure the Changjiang River's effect on its tributary lake, East Dongting (Lake ED). The $Q_{\text {Changiang }}$ in the legend is the runoff volume of the Changjiang $\operatorname{River}\left(\mathrm{m}^{3} / \mathrm{s}\right), H_{\text {Lake }}$ is the water level of Lake ED (m), $Q_{\text {Lake }}$ is the discharge volume of Lake ED $\left(\mathrm{m}^{3} / \mathrm{s}\right)$. When runoff of the Changjiang River is in the $21,500-27,500 \mathrm{~m}^{3} / \mathrm{s}$ range, $15,500-21,500 \mathrm{~m}^{3} / \mathrm{s}$ range, and $9500-15,500 \mathrm{~m}^{3} / \mathrm{s}$ range, the rating curves of Lake ED fit well $\left(R^{2}=0.82,0.86,0.80\right.$, respectively) and are nearly parallel with each other. As noted, when the runoff of the Changjiang River decreases with a step interval of $6000 \mathrm{~m}^{3} / \mathrm{s}$ from $27,500 \mathrm{~m}^{3} / \mathrm{s}$ to $9500 \mathrm{~m}^{3} / \mathrm{s}$, the lake water level drops by $h_{1}$ (in the maximum river runoff range) and $h_{2} \mathrm{~m}$ (in the minimum river runoff range) at equal lake discharge. Hence, we interpreted the distances, for example, $h_{1}$ and $h_{2}$, as the impact of the Changjiang River on the water level of Lake ED during specific hydrologic conditions.

different hydrologic conditions of the Changjiang River, i.e., the spacing survey measurement of those rating curves (Figure 2), which offers both quantitative insights into the effect and allows for actual physical interpretation of the river-lake interaction.

\section{Results}

\subsection{Recent water level changes in Lake East Dongting}

As shown in Figure 3a, the linear regression of the annual mean water level from 1980 to 2014 shows a general downward trend (slope: $-0.02 \mathrm{~m} \mathrm{year}^{-1}$ ). The annual average water level in Lake ED decreases by $0.48 \mathrm{~m}$ from 2003-2014 when compared to the previous decades (1980-2002). The four seasonal mean water levels (Figures 3b-3e) show various fluctuating trends from 1980-2014. In summer and autumn, the linear regressions of the seasonal mean water level show a similar declining trend to that of the annual mean water level but at differing amplitudes (slope: -0.02 and $-0.08 \mathrm{~m} \mathrm{year}^{-1}$, respectively). Among them, the ebb of the water level in summer during 1980-2014 is not significant $(P=0.36)$. While the decline during the summer months after 2003 is observable, that is $0.87 \mathrm{~m}$ lower than the 1980-2014 average. The reduction of water levels in autumn is significant $(P<$ 0.001). The most dramatic declines since 2003 occurred in autumn, of which the seasonal mean water level is $1.55 \mathrm{~m}$ lower than the average from 1980-2002. In winter and spring, however, the linear regressions of the seasonal mean water level show an upward trend (both the slopes of these seasons were 0.01 ), although the average rises since 2003 are both within $0.1 \mathrm{~m}$ (by only $0.07 \mathrm{~m}$ in winter and $0.02 \mathrm{~m}$ in spring). In sum, there is a clear decrease in the water levels of the Lake ED during 1980-2014; however, the changing trend of the lake 
level is due to obvious seasonal variations. The declines in summer and autumn are substantial, while there are merely slight risings for water levels in winter and spring.

(a) Annual average

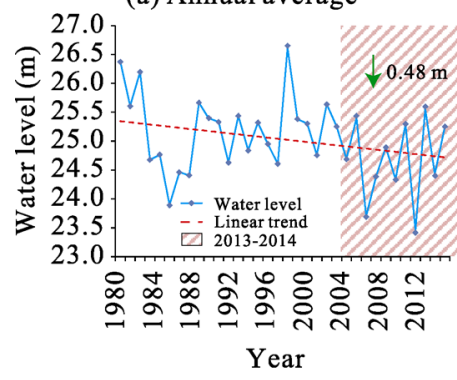

(d) Winter average

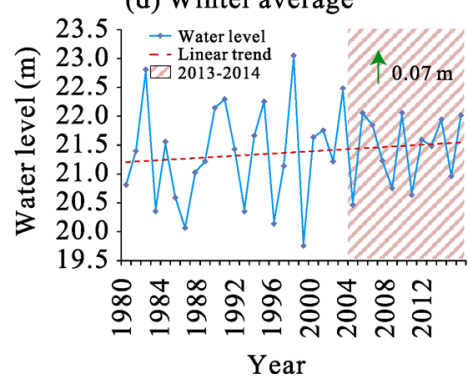

(b) Summer average

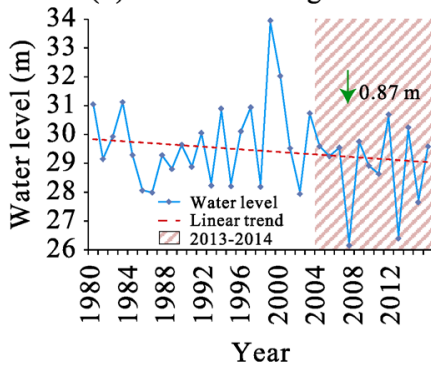

(c) Autumn average

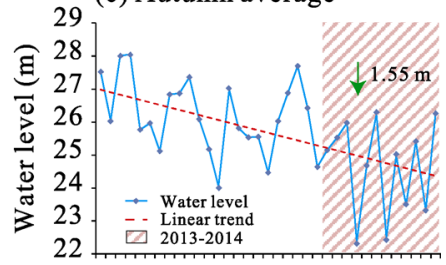

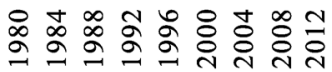
Year

(e) Spring average

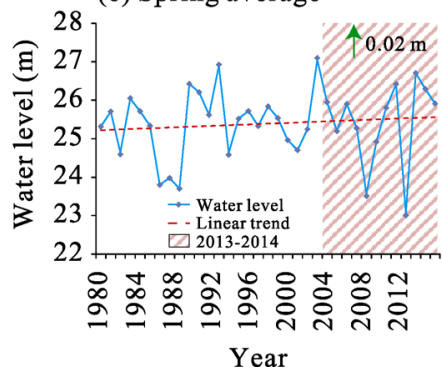

Figure 3 Water level changes within Lake East Dongting during 1980-2014

\subsection{The effect of Changjiang River on Lake East Dongting}

The stage-discharge curves of Lake ED reflect the Lakes' capacity to convey water into the downstream Changjiang River, which depends largely on water regimes of the Changjiang River, as shown in Figure 4a. The rating curves of Lake ED were fitted separately in each group divided by the evenly spaced Changjiang River runoff with an interval of $3000 \mathrm{~m}^{3} / \mathrm{s}$. The maximum and minimum of the river runoff are respective $3510 \mathrm{~m}^{3} / \mathrm{s}$ and $45,400 \mathrm{~m}^{3} / \mathrm{s}$ during 1980-2014, thus 14 rating curves of Lake ED were fitted between the available river runoff range. They are marked by letters from $\mathrm{A}$ to $\mathrm{N}$ to list the water regime of the Changjiang River from dry to flood in alphabetical order. All the rating curves of Lake ED fit well with the $R^{2}$ scoring an average of 0.81 (SD 0.05). The spacing between adjacent rating curves illustrates the impact of the Changjiang River on water regimes of the Lake ED at the given level of river runoff. For example, the bottom orange line marked by A and the penultimate gray line marked by B in Figure 4a are the rating curves of Lake ED when the runoff of the Changjiang River is in the $3500-6500 \mathrm{~m}^{3} / \mathrm{s}$ range and the $6500-9500 \mathrm{~m}^{3} / \mathrm{s}$ range, respectively. In these two situations, as runoff of the Changjiang River increased by a step with an interval of $3000 \mathrm{~m}^{3} / \mathrm{s}$ from $A$ to $B$, the average lake water level at equal lake discharge increased by nearly $1.45 \mathrm{~m}$. The physics concept of the $1.45 \mathrm{~m}$ means: a variation of $3000 \mathrm{~m}^{3} / \mathrm{s}$ in Changjiang River runoff would change the lake water level by $1.45 \mathrm{~m}$ when the river runoff at the level of $6500 \mathrm{~m}^{3} / \mathrm{s}$ or so (effectively within the range $[3500,9500] \mathrm{m}^{3} / \mathrm{s}$ ). In the same way, the spacing between any pair of adjacent rating curves was estimated, which versus the corresponding median values of the Changjiang River runoff interval limitation was then charted in Figure 4b. It depicts the impact of the Changjiang River on Lake 
ED in a quite clear and intuitive way.

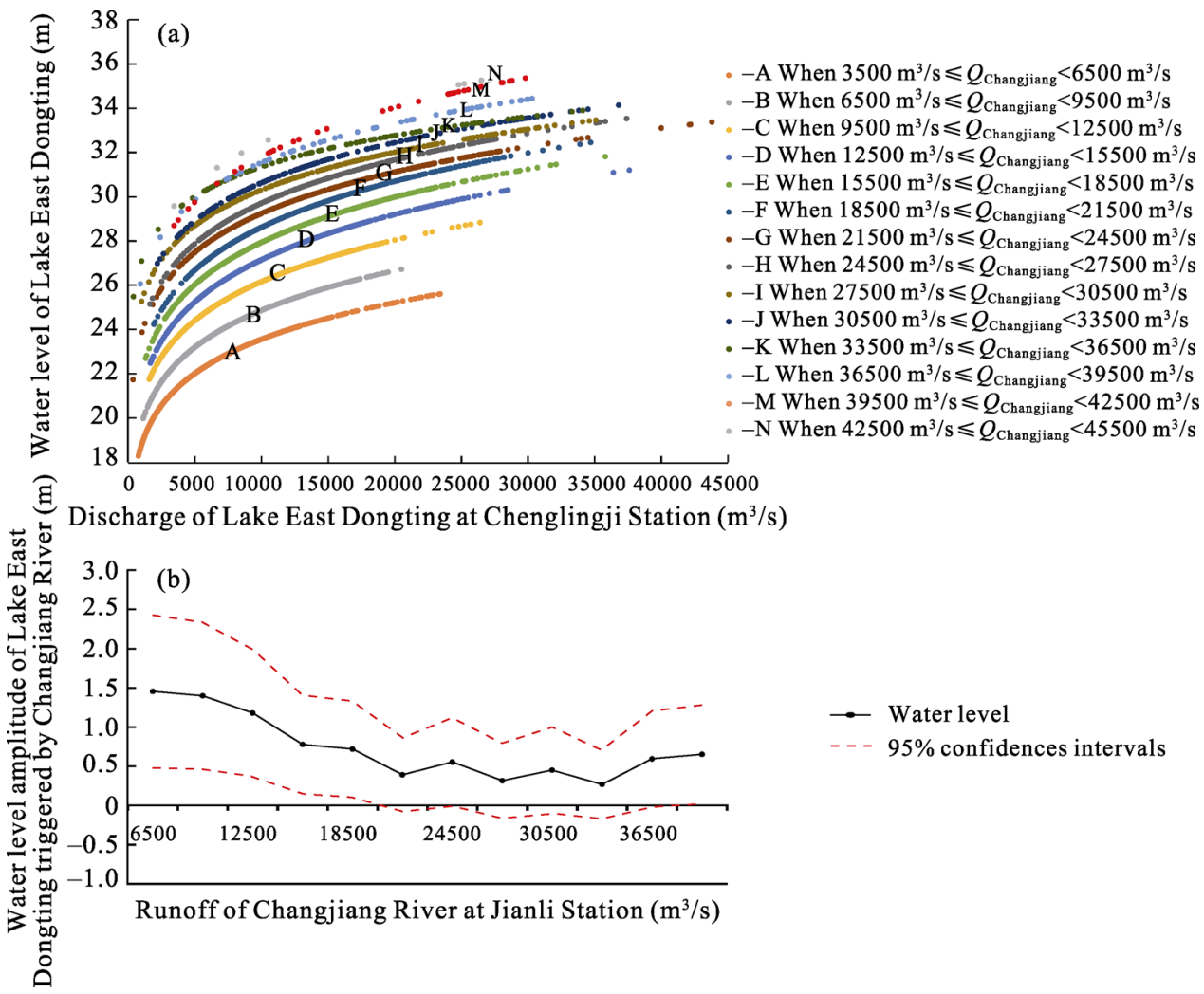

Figure 4 The effect of the Changjiang River on Lake East Dongting (Lake ED) at various runoff magnitudes. (a) The rating curves of Lake ED in various categories separated by the interval limitations of the Changjiang River runoff. The $Q_{\text {Changiang }}$ in the legend is the discharge of the Changjiang River $\left(\mathrm{m}^{3} / \mathrm{s}\right)$. (b) The spacing between adjacent lake rating curves, interpreted as the effect of the Changjiang River to Lake ED, at corresponding Changjiang River runoff magnitudes.

As shown in Figure 4b, the degree to which the Changjiang River affects Lake ED varies with the river runoff magnitudes. The strongest influence of the Changjiang River occurs when the river runoff is less than $18,500 \mathrm{~m}^{3} / \mathrm{s}$, which usually occurs in the spring, autumn, and winter months. The Changjiang River with runoff in this range can raise the water level of Lake ED by approximately $1.1 \mathrm{~m}$ per $3000 \mathrm{~m}^{3} / \mathrm{s}$. When the river runoff is higher than $18,500 \mathrm{~m}^{3} / \mathrm{s}$, which usually occurs in the summer months, the impact of Changjiang River begins to decrease rapidly and, by $33,500 \mathrm{~m}^{3} / \mathrm{s}$, the influence is less than $0.3 \mathrm{~m}$ per 3000 $\mathrm{m}^{3} / \mathrm{s}$. On average, the influence of Changjiang River to water levels of Lake ED with river runoff in the $18,500-33,500 \mathrm{~m}^{3} / \mathrm{s}$ range is only $0.4 \mathrm{~m}$ per $3000 \mathrm{~m}^{3} / \mathrm{s}$. When the river runoff becomes higher than $36,500 \mathrm{~m}^{3} / \mathrm{s}$, which only occurs during the peak summer floods, the influence extent of the Changjiang River recovers slightly to around $0.6 \mathrm{~m}$ per $3000 \mathrm{~m}^{3} / \mathrm{s}$.

The Changjiang River acts as the local erosion base level for Lake ED. So, changes in the hydrologic condition of the Changjiang River will influence the lakes' capacity to convey water at the outlet. From the quantitative point of view, our results indicate that the influence of the Changjiang River on the conveying ability of Lake ED undergoes seasonal turnovers. This process is a result of the varying hydrological processes in both Lake ED and the 
Changjiang River, as well as the associated river-lake interaction. Hence, before we explain this result, it is critical to reiterate the annual variations of water regime in the middle reaches of the Changjiang River. This brief review will help readers to comprehend the river-lake interaction discussed in this section.

In spring, the Lake ED is significantly recharged from its catchment basin due to the Asian monsoons. Increasing discharge of Lake ED causes a rapid rising lake water level and steep water gradient at the outlet. Given the large amount of lake discharge and steep water surface gradient at outlet, even a small variation in Changjiang River runoff can cause a dramatic amplitude of lake water level in spring. As is illustrated in Figure 4b, the Changjiang River with runoff less than $18,500 \mathrm{~m}^{3} / \mathrm{s}$ is of the most powerful in a year, which can raise the water level of Lake ED by approximately $1.1 \mathrm{~m} \mathrm{per} 3000 \mathrm{~m}^{3} / \mathrm{s}$.

In summer, because of the northwestward flow of the monsoon front, discharge of the Lake ED diminishes, and the Changjiang River runoff increases. The decreasing discharge of Lake ED is heavily blocked by the increase of the Changiiang River runoff and the water gradient at the lake outlet diminishes accordingly. In this condition, the banked-up water levels of Lake ED become higher and reach the highest point of the year despite the decreasing discharge of Lake ED. Thus, the high-water level of Lake ED in summer is the result of the increased blocking effect of the Changjiang River, not the decreasing lake recharge. In this condition, although the Changjiang River has a strong blocking effect on Lake ED, the river runoff increases at such a high level can only raise the lake water level at a minor degree without backing up by the discharge from the lake watershed. Hence, the influence of the Changjiang River with runoff in the $18,500-33,500 \mathrm{~m}^{3} / \mathrm{s}$ range is weak, which can raise the water level of Lake ED by only $0.4 \mathrm{~m}$ per $3000 \mathrm{~m}^{3} / \mathrm{s}$, as is illustrated in Figure $4 \mathrm{~b}$. When it comes to the peak summer floods, i.e., when the Changjiang River runoff is greater than $33,500 \mathrm{~m}^{3} / \mathrm{s}$, the influence of the Changjiang River on Lake ED becomes stronger slightly, but still not as significant as that in spring.

In autumn, the reduction of runoff of the Changiiang River weakened its blocking effect on the outflow of the lake, which could eventually cause the Lake ED to recede. The lake level falls even lower in winter. During these periods, the water gradient at the lake outlet turns to steep again and the lake water level is dominated by the lake discharge again. This situation is similar to that of spring except for the magnitude that does not match. Thus, the influence of the Changjiang River on Lake ED is also significant in autumn and winter like the conditions in spring.

Overall, by comparing the rating curves of Lake ED under different conditions of the Changjiang River, we quantitatively evaluated the influence of the Changjiang River on the tributary Lake ED.

\subsection{Water level variations in Lake East Dongting triggered by the changing hydro- logic condition of the Changjiang River}

The impact of the Changjiang River on Lake ED at different river runoff magnitudes was quantitatively evaluated in the previous section. In this section, we collected further information about changes in the runoff of the Changjiang River before and after 2003, which could partition the lake water level variations triggered by the Changiiang River.

Seasonal turnovers of the runoff of the Changjiang River before and after 2003 are illus- 
trated in Figure 5. The box plot for summer (Figure 5a) indicates that the interquartile range of the summer runoff of the Changjiang River in 1980-2014 is within the 18,500$33,500 \mathrm{~m}^{3} / \mathrm{s}$ range. The above-mentioned analysis has estimated the influence of the Changjiang River at the given level of river runoff. Hence, as the Changjiang River runoff in summer decreased by $2354 \mathrm{~m}^{3} / \mathrm{s}$ after 2003 , the drop of water level of Lake ED caused by the receding of the Changjiang River should be $0.31 \mathrm{~m}$ proportionally. In the other three seasons, turnovers of the Changjiang River runoff before and after 2003 are respectively $-2510 \mathrm{~m}^{3} / \mathrm{s}$ in autumn, $803 \mathrm{~m}^{3} / \mathrm{s}$ in winter and $363 \mathrm{~m}^{3} / \mathrm{s}$ in spring. Consequently, the variation amplitudes of the water level of Lake ED triggered by the turnovers of the Changjiang River runoff before and after 2003 should be $-0.92 \mathrm{~m}$ in autumn, $0.30 \mathrm{~m}$ in winter and 0.13 in spring, as shown in Figure 6.


Runoff of Changjiang River at Jianli Station $\left(\mathrm{m}^{3} / \mathrm{s}\right)$


Figure 5 Comparison of the Changjiang River runoff in all four seasons between 1980-2002 and 2003-2014. (a), (b), (c) and (d) are the box plots illustrating the daily mean runoff of the Changjiang River in summer, autumn, winter and spring, respectively.

Additionally, the water-level amplitude of Lake ED in each season from observational hydrologic data was also calculated and illustrated in Figure 6. As shown in Figure 6, we

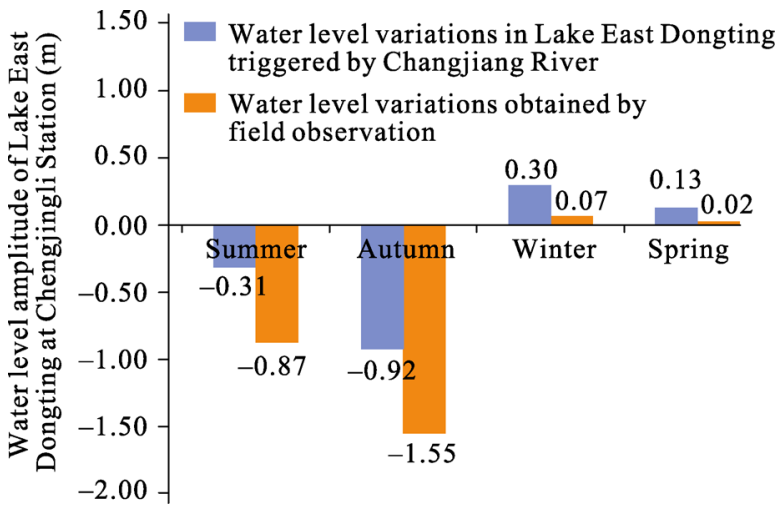

Figure 6 Comparison of the predicted Changjiang River component influences and the observed lake water level variations in all four seasons between 1980-2002 and 2003-2014 noted that the observed water level drops in summer and autumn are larger than the lake level reductions triggered by the decreasing Changjiang River runoff. Thus, the decline of the lake water level after 2003 triggered by the Changjiang River would most likely be further exacerbated by some other underlying factors. In winter and spring, the observed water level rises are less than the water level rises triggered by the increasing Changjiang River runoff. That is, the lake water 
level that should be severely elevated by the Changiiang River would most likely be reduced by some other underlying factors. Thus, there must be underlying factors that pulling down the lake water level throughout the year, which will be briefly analyzed in the following section.

\section{Discussion}

\subsection{Other factors associated with water regime variation of Lake East Dongting}

The water regime changes in Lake ED may have many other causes in addition to the Changjiang River. Many scholars have described and speculated about the reasons for the lower annual lake stage and the shifting seasonal water-level fluctuation patterns. They have mainly attributed them to the possible decreased lake inflow and the possible morphological changes. Thus, we verified both the two assumed factors in this study. The results show that (1) the lake inflow in all seasons tended to decrease in 1980-2014, as shown in Table 1. However, none of them passes the significant test at the 0.05 level. That is, the lake inflow in 2003-2014 only has a slight decrease than it was in 1980-2002. (2) The morphological changes at the outlet of Lake ED did include slight scouring in the lake bed in 2007-2012 when comparing the channel profiles in 1984, as shown in Figure 7. The most dramatic elevation drop along the Chenglingji Transect is $1.40 \mathrm{~m}$, which exactly occurs at the thalweg of the lake bed. But the dramatic scouring only occurs near the narrow channel (within a narrow distance range of approximately $900-1000 \mathrm{~m}$ to the initial point of the Transect). Elevation drops at other part of lake bed are slight (elevation drop $<0.3 \mathrm{~m}$ ). Overall, the decreases of lake inflow and the eroded lake bed do have contributed throughout the year to lower the water level of Lake ED over the last 30 years. But they only exacerbated the reduction of water level to a small degree. The changing water regime of Lake ED, especially the shifted seasonal water level fluctuation pattern, is impacted mainly by hydrologic changes of the Changjiang River.

Table 1 Key parameters of linear trend analysis for the total inflow of Lake East Dongting from its four tributary rivers

\begin{tabular}{lccc}
\hline & $\begin{array}{c}\text { Slope } \\
\left.\text { (billion } \mathrm{m}^{3} / \mathrm{yr}\right)\end{array}$ & $P$-value & $\begin{array}{c}\text { Intercept } \\
{\text { (billion } \mathrm{m}^{3} \text { ) }}\end{array}$ \\
\hline Spring & -0.69 & 0.73 & 624 \\
Summer & -0.49 & 0.87 & 537 \\
Autumn & -0.47 & 0.68 & 168 \\
Winter & -1.98 & 0.43 & 396 \\
\hline
\end{tabular}



Figure 7 Channel profile changes near the Chenglingji hydrologic station at the outlet of Lake East Dongting

\subsection{Effects of the Three Gorges Dam on Lake East Dongting}

The Changjiang River affects the Lake ED through variation of its blocking effect because 
of the changing river runoff. While the Changjiang River runoff is further controlled by the regulations of the Three Georges Dam (TGD). The TGD, which is located right in the main section of the Changjiang River, holds many records in the history of engineering. It is used to balance the flow of Changjiang River since 2003. As shown in Figure 8, water levels in TGD show a gradual fall in winter, a fluctuating fall in spring, a largely stable in summer and a sharp rise in autumn. This is because that the TGD generally releases water in winter for power generation and relieving the drought conditions downstream. It continues to drain in spring for preparing of flood control. The TGD in summer does not release extra water, or impound water unless at times of extreme flood events. In autumn, the TGD begins to fill with water for the drought conditions in the following dry seasons. Hence, the Changjiang River runoff gets larger in winter and spring, in contrast, gets smaller in summer and autumn under the condition of TGD control versus the natural condition. As the above results show, these variations further impact water regimes of the tributary lakes of the Changjiang River downstream the TGD. Specifically, the extra water releasing of TGD in winter and spring leads to an increasing of the Changjiang River runoff, which further strengthens the blocking effect of the Changjiang River on Lake ED and results in a rise of lake water level at equal lake discharge. While the water impoundment of the TGD in summer and autumn leads to a decreasing of the Changjiang River runoff, which further weakens the reversing effect of the Changjiang River on Lake ED, resulting in lowering water levels in Lake ED. Hence, we confirmed that the abnormal water regime changes in Lake ED after 2003 were indirectly attributable to the operation of the TGD.

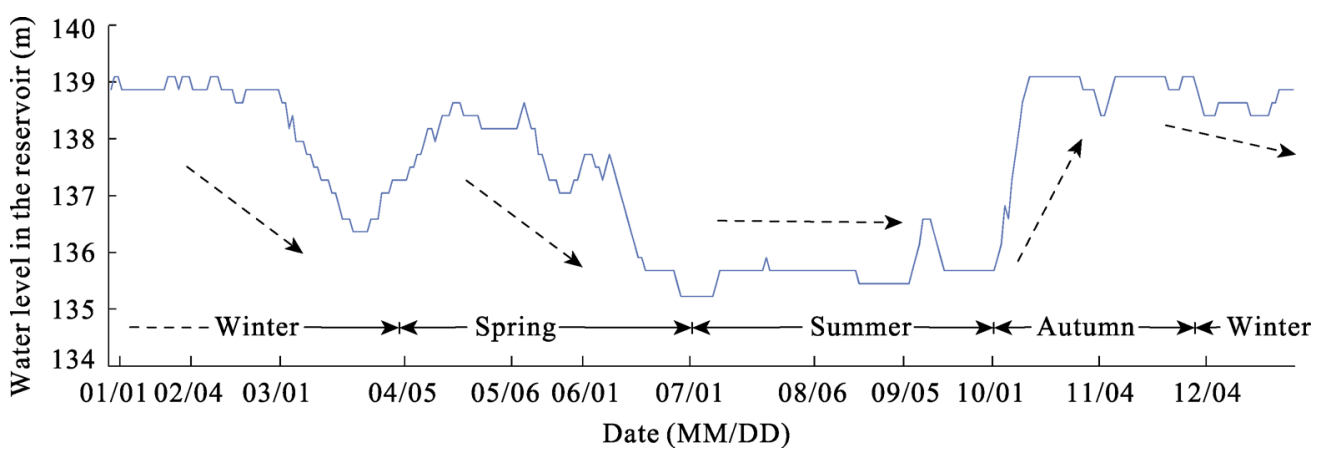

Figure 8 Variations of water levels in the reservoir of The Three Gorges Dam (using the situation in 2007 as an example)

\section{Conclusions}

Based on the analysis of a typical district, i.e., the Lake East Dongting (Lake ED) and the Changjiang River, we demonstrated that a river can impact the water regime of its tributary lakes significantly. This study presented a method based on dynamically corrected rating curves to measure the impact of a trunk river on its tributary lakes, which is among the first to deliver both quantitative results and allow for physical interpretation of this issue. Additionally, in this study, we also attempted to clarify other relative factors for lake water regime changes, including the total inflow of the lake and the morphological changes at the lake outlet. The indirect effects of TGD on Lake ED through regulation of the Changjiang 
River runoff were also briefly introduced in this research.

(1) Water regime changes in Lake ED during 1980-2014 were revealed in this study. The annual mean water level of Lake ED has a clear downward trend (slope: $-0.02 \mathrm{~m}$ year $^{-1}$ ) during 1980-2014. The seasonal water level fluctuation pattern of Lake ED has been shifted dramatically. The lake water levels in autumn and summer have a substantial decline (slope: -0.02 and $-0.08 \mathrm{~m}$ year $^{-1}$, respectively). While the lake water levels in winter and spring have a slight rise (slope: 0.01 and $0.01 \mathrm{~m} \mathrm{year}^{-1}$, respectively).

(2) The Changjiang River does exert a huge impact on the water regimes of Lake ED. The influence extent of the Changjiang River varies substantially with the river runoff magnitudes. A variation of $3000 \mathrm{~m}^{3} / \mathrm{s}$ in Changjiang River runoff would change the lake level by about $1.1 \mathrm{~m}$ when the river runoff is less than $18,500 \mathrm{~m}^{3} / \mathrm{s}$, by about $0.4 \mathrm{~m}$ when the river runoff is in the $18,500-33,500 \mathrm{~m}^{3} / \mathrm{s}$ range, and by about $0.6 \mathrm{~m}$ when the river runoff is greater than $33,500 \mathrm{~m}^{3} / \mathrm{s}$.

(3) The change in hydrologic conditions of the Changjiang River is the main reason for water regime variations in Lake ED. Turnovers of the Changjiang River runoff before and after 2003 are respective $-2354 \mathrm{~m}^{3} / \mathrm{s}$ in summer, $-2510 \mathrm{~m}^{3} / \mathrm{s}$ in autumn, $803 \mathrm{~m}^{3} / \mathrm{s}$ in winter and $363 \mathrm{~m}^{3} / \mathrm{s}$ in spring. Consequently, the variation amplitudes of the water level of Lake ED triggered by the turnovers of the Changjiang River runoff should be $-0.31 \mathrm{~m}$ in summer, $-0.92 \mathrm{~m}$ in autumn, $0.30 \mathrm{~m}$ in winter and 0.13 in spring. Influenced by the reduced lake inflow and the eroded lake bed, the drops of lake water level in summer and autumn triggered by the decreasing Changjiang River runoff are partly aggravated. While the rises of lake water level in winter and spring are partly offset.

(4) The periodic impounding and draining of the TGD is closely related to the variations in water levels of Lake ED. The abnormal water regime changes in Lake ED after 2003 were indirectly attributable to the operation of the TGD. Given that a growing number of water conservancy projects on the Changjiang River would continue to regulate the river flow, the changing water regimes of Lake ED would most likely continue. Regulation of these water conservancy projects that take water regimes of tributary lakes into account in an overview should be proposed.

\section{References}

Chang J, Li J B, Lu D Q et al., 2010. The hydrological effect between Jingjiang River and Dongting Lake during the initial period of Three Gorges Project operation. Journal of Geographical Sciences, 20(5): 771-786.

Cooke G D, Welch E B, Peterson S et al., 2005. Restoration and Management of Lakes and Reservoirs. United States: CRC Press.

Dai X, Wan R R, Yang G S, 2015. Non-stationary water-level fluctuation in China's Poyang Lake and its interactions with Yangtze River. Journal of Geographical Sciences, 25(3): 274-288.

Darwish K, Smith S E, Torab M et al., 2017. Geomorphological changes along the Nile Delta coastline between 1945 and 2015 detected using satellite remote sensing and GIS. Journal of Coastal Research, 33(4): 786-794.

Dong M, Zou B, 2014. Research in the Dongting Lake: Resource Utilization, Environment Protection and Regional Development. Changsha: Central South University Press.

Dottori F, Martina M L V, Todini E, 2009. A dynamic rating curve approach to indirect discharge measurement. Hydrology and Earth System Sciences, 13(6): 847-863.

Dynesius M, Nilsson C, 1994. Fragmentation and flow regulation of river systems in the Northern 3rd of the 
World. Science, 266(5186): 753-762.

Gao J H, Jia J, Kettner A J et al., 2015. Reservoir-induced changes to fluvial fluxes and their downstream impacts on sedimentary processes: The Changjiang (Yangtze) River, China. Quaternary International. http://dx.doi.org/10.1016/j.quaint.2015.03.015.

Guo H, Hu Q, Zhang Q et al., 2012. Effects of the Three Gorges Dam on Yangtze River flow and river interaction with Poyang Lake, China: 2003-2008. Journal of Hydrology, 416(24): 19-27.

$\mathrm{Hu}$ Q, Feng S, Guo H et al., 2007. Interactions of the Yangtze River flow and hydrologic processes of the Poyang Lake, China. Journal of Hydrology, 347(1/2): 90-100.

Jalbert J, Mathevet T, Favre A C, 2011. Temporal uncertainty estimation of discharges from rating curves using a variographic analysis. Journal of Hydrology, 397(1/2): 83-92.

Khasraghia M M, Sefidkouhia M A G, Valipour M, 2015. Simulation of open- and closed-end border irrigation systems using SIRMOD. Archives Agronomy and Soil Science, 61(7): 929-941.

Leon J G, Calmant S, Seyler F et al., 2006. Rating curves and estimation of average water depth at the upper Negro River based on satellite altimeter data and modeled discharges. Journal of Hydrology, 328(3/4): 481-496.

Li J B, Zhou Y Q, Ou C M et al., 2013. Evolution of water exchange ability between Dongting Lake and Yangtze River and its response to the operation of the Three Gorges Reservoir. Acta Geographica Sinica, 68(1): 108-117. (in Chinese)

Li Y L, Zhang Q, Werner A D et al., 2016. The influence of river-to-lake backflow on the hydrodynamics of a large floodplain-lake system (Poyang Lake, China). Hydrological Processes, 31(1): 117-132.

Liao M S, Guo J, 2014. Characteristics of temperature and precipitation for the last 32 years in Dongting Lake Basin. Journal of Hengyang Normal University, (6): 109-114. (in Chinese)

Liu Y B, Wu G P, Zhao X S, 2013. Recent declines in China's largest freshwater lake: Trend or regime shift? Environmental Research Letters, 8(1): 014010.

Peters D L, Buttle J M, 2010. The effects of flow regulation and climatic variability on obstructed drainage and reverse flow contribution in a Northern River-Lake-Delta Complex, Mackenzie Basin Headwaters. River Research Applications, 26(9): 1065-1089.

The Ramsar Convention, 2012. The List of Wetlands of International Importance, 25 April 2012.

Wang J, Sheng Y, Gleason C J et al., 2013. Downstream Yangtze River levels impacted by Three Gorges Dam. Environmental Research Letters, 8: 575-591.

Waugh J R, Webby M G, 2006. Hydraulic behaviour of the outlet of Lake Wakatipu, Central Otago, New Zealand. Journal of Hydrology (New Zealand), 45: 29-40.

Wolfs V, Willems P, 2014. Development of discharge-stage curves affected by hysteresis using time varying models, model trees and neural networks. Environmental Modelling \& Software, 55: 107-119.

Wu J G, Huang J H, Han X G et al., 2008. The Three Gorges Dam: An ecological perspective. Frontiers in Ecology \& the Environment, 2(5): 241-248.

Yang S L, Zhang J, Xu X J, 2007. Influence of the Three Gorges Dam on downstream delivery of sediment and its environmental implications, Yangtze River. Geophysical Research Letters, 34(10): L10401.

Yuan Y J, Zeng G M, Jie L et al., 2015. Variation of water level in Dongting Lake over a 50-year period: Implications for the impacts of anthropogenic and climatic factors. Journal of Hydrology, 525: 450-456.

Zhang Q, Ye X C, Werner A D et al., 2014. An investigation of enhanced recessions in Poyang Lake: Comparison of Yangtze River and local catchment impacts. Journal of Hydrology, 517: 425-434.

Zhao J K, Li J F, Yan H et al., 2011. Analysis on the water exchange between the main stream of the Yangtze River and the Poyang Lake. Procedia Environmental Sciences, 10: 2256-2264. 